\title{
Generation of authigenic clay minerals during diagenesis and their influences on porosity and permeability of Oligocene sandstone reservoir rocks, from a well in the west of Cuu Long basin
}

- Lieu Kim Phuong

- Ho Minh Toan

- Doan Thi Thuy

- Bui Thi Ngoc Phuong

Analysis Laboratory Center, Vietnam Petroleum Institute (VPI)

(Manuscript Received on August 05 ${ }^{\text {th }}, 2014$; Manuscript Revised November 11 $1^{\text {th }}, 2014$ )

\section{ABSTRACT:}

Porosity and permeability play a prerequisite role for hydrocarbon reservoirs and fluid flows, especially in sandstone reservoir rocks. The rocks with high porosity decrease down to lower porosity with increasing burial depth due to compaction, cementation and precipitation of authigenic minerals in pores from over saturated solution of minerals. The detailed study of the authigenic clay mineral formation in pore spaces of sandstone reservoir rocks is therefore crucial to estimate the degree of reservoir rock quality.

In this study 20 sandstone cores taken from the interval burial depths of 3,700 m-4,200 m from Oligocene sandstone sequence of a well in the West of the Cuu Long basin, offshore Vietnam, were analyzed by SEM and thin section. Authigenic clay minerals were formed due to temperature and chemistry changes and owing to dissolution of less stable minerals in these burial depths. Authigenic chlorite mineral appears quite abundantly and illite is less frequently. Chlorite was formed from the elements $A$ l and Si, which were released from dissolved grains and $\mathrm{Fe}$ and $\mathrm{Mg}$ supplied from breakdown of the ferromagnesian minerals of rock fragments and matrix components into pore waters in the burial stage. Illite is associated with the expense of grain dissolution of feldspar, volcanic fragment. Chlorite mostly appears as a coating or mats comprising of small pseudo-hexagonal crystals arranged perpendicular to detrital grain surfaces. Grainrimming chlorites on quartz grain are responsible for the preservation of the porosity in the sandstones because they limit the formation of quartz overgrowth.

Additionally fibrous or flaky illite bridging the pores between the grains creates permeability barriers to fluid flows through the sandstones. Thus illite significantly reduces the permeability but to lesser extent affect porosity. Locally, smectite mixes with illite or chlorite and is not abundant in the studied samples. It therefore has no significant impact on the porosity and permeability as well.

The variations of the porosity and the permeability of the studied sandstones depend on the generated degree and the arranged patterns of chlorite and illite in pore spaces.

Key words: SEM, Chlorite-illite, Porosity, Permeability, Sandstone. 


\section{INTRODUCTION}

Cuu Long basin is a Tertiary rift basin situated on the southern shelf of Vietnam. It stretches out an area of roughly $36,000 \mathrm{~km}^{2}$. As so far, the Cuu Long basin is being estimated the largest petroleum reserve in Vietnam with Bach Ho, Rong, Rang Dong, Hong Ngoc, $\mathrm{Su} \mathrm{Tu}$ Den, etc. exploiting wells [1]. According to the previous investigation, the Oligocene sandstone reservoir rocks are estimated the good hydrocarbon reservoir quality [2]. However, the properties of Oligocene sandstones are unstable as the porosity is varying from low to high levels and these sandstones are being explored and exploited hydrocarbon in the Cuu Long basin [1].

Authigenic clay mineral assemblages in Oligocene sandstone reservoir rocks are an important role in hydrocarbon exploration because they have significant effects on sandstone properties in terms of porosity and permeability. The properties are related to hydrocarbon reservoir quality and fluid flows through pores in sandstones. Authigenic clay minerals are formed during post depositional processes. Clay minerals are distinct distribution pattern and morphologies. Therefore, the investigation of the authigenic clay mineral assemblages, which are formed in pore spaces of the Oligocene sandstone reservoir rocks in the Cuu Long basin, not only qualifies the change in porosity and permeability during the diagenetic processes of rocks, but also allows to estimate the amount of reserved oil in the reservoir rocks.

\section{METHODS}

To study the formation of authigenic clay assemblages in pore spaces, sandstones were collected from core samples in Oligocene sequence of a well in the Cuu Long basin at the depth from 3,700 $\mathrm{m}$ to 4,200 $\mathrm{m}$, offshore Vietnam. Then selected samples were analyzed by thin section petrography, scanning electron microscopy (SEM), energy dispersive X-ray system (EDX).

Optical microscopy: Pores within sandstones were stained blue epoxy resin. Thin sections were either polished or covered with glass after staining. All thin sections were studied with petrographic microscope under plane and cross polarized light. The investigation reveals the characteristics of detrital grains, texture, authigenic minerals and porosity. Determination of mineral composition and visible porosity was performed by the point counting data of 300 points per thin section [3, 4]. The sandstone was classified as [5] classification. The grain size distribution of sandstone was measured by long diameter of 100 grains per thin section. The textural terminology as mean grain size, grain sorting, roundness and grain contacts was based on $[6,7]$ classifications.

Scanning electron microscopy (SEM) and energy dispersive X-ray system (EDX): Crystal morphology of the authigenic minerals, type of authigenic minerals, their relation to framework grains and pore network were examined with SEM and element analysis was done by EDX. This analysis reveals the texture and fabric of sandstone and aids to recognize the post depositional alteration. The sandstone samples were separated into small pieces and mounted on a sample holder. The samples were coated with a thin gold layer in a polar on sputter coater to improve the resolution. The scanning electron microscope JEOL (JSM$5600 \mathrm{LV}$ ) system was operated with beam voltages of 20 $\mathrm{kV}$ and with $15 \mathrm{kV}$ for the energy dispersive X-ray system (EDX). SEM images were taken digitally in secondary electron (SE) mode and as chemical element spectra.

\section{RESULTS}

The Oligocene sandstone reservoir rocks are varying from very fine to medium in grain size, poorly, moderately to well sorting. The sandstones with subangular, subround and round clastic grains indicate the sediments are transported not far from the supplied source. The grain to grain contacts are mainly point to point and parallel to the long axis of the grains, suggesting that the grains were mechanically compacted. At higher depth the grains were more strongly compacted so many of the contacts between grains have undergone solution leading to the penetration of one grain into another. Therefore, the grain contacts are concavo - convex. The most abundant component of the investigated sandstones is quartz, roughly $20 \%$ to $30 \%$ in total of sandstone volume. Less abundant amounts are alkaline feldspar $5 \%-15 \%$, plagioclase $10 \%-20 \%$ with subordinate rock fragments such as volcanic rock, chert, quartzite and granite indicating that the clastic grains derived

\section{Trang 22}


from weathered igneous and/or volcanic rocks. According to R. L. Folk 1974, 1980 classification [5], the sandstones are as classified arkose rocks, which are less than $15 \%$ detrital matrix (figure 1). With grain textural features, framework grains and inhomogeneous grain size showing that the detrital grains deposited in the environment with unstable flow energy. The previous investigations by Tran Le Dong and Phung Dac Hai, 2000 [1] demonstrated that the Oligocene sandstones were formed in fluvial environment and alluvial plain - lacustrine.

The porosity of the investigated sandstones, which are generated by arrangement of detrital grains, is highly controlled by diagenetic processes as cementation, compaction and dissolution. The result reveals that the pore spaces in the sandstones are varying and in low levels in estimation. The pores are occluded by clay matrix, carbonate cement and authigenic minerals. In addition, the visible porosity is enhanced by dissolution of less stable grains as feldspar, volcanic fragment, etc. (figure 1).
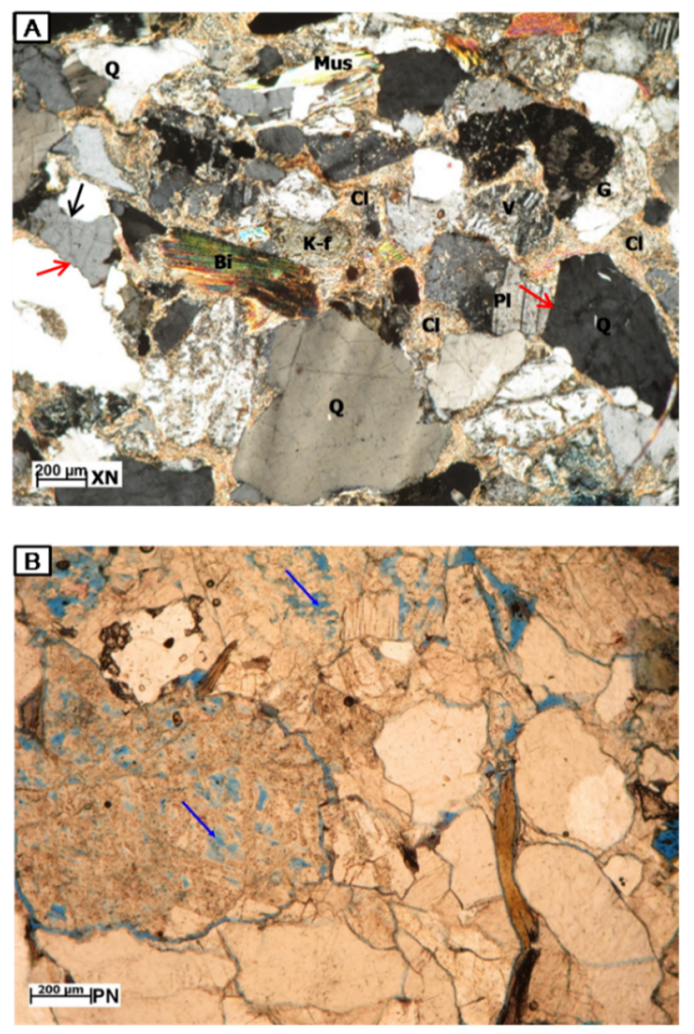

Figure 1: Image A, cross polarized light, shows sandstone taken at $3853 \mathrm{~m}$ depth. Image B, plane polarized light, sandstone was taken from $3727 \mathrm{~m}$ depth.
The photomicrograph A is showing arkose. The grain contacts in the sandstone are tangential and long axis of grains (arrows). The abundant framework grain composition is quartz $(\mathrm{Q})$, including monocrystalline and polycrystalline quartz, alkaline feldspar (K-f) and plagioclase grains $(\mathrm{Pl})$, minor amounts of rock fragments as granite $(\mathrm{G})$, volcanic rock, chert and mica including biotite (Bi) and muscovite (Mus) which shows bright color under cross polarized light. The detrital grains are subangular, subrounded to rounded shape. The clastic grains are packed by clay $(\mathrm{Cl})$. The photomicrograph B shows the sandstone porosity with open pores having blue color and leached feldspar grains yielding secondary pores (arrows).

The studied sandstones have undergone multiple diagenetic phases. Many authigenic minerals and cement generations are formed during diagenesis. Additionally, the dissolution of less stable minerals e.g. feldspar, volcanic fragment and color minerals is owing to pressure, temperature and chemistry changes that are supplying ions into pore spaces. This is favorable conditions for clay mineral precipitation. The clay mineral assemblages in pores are the main reason to deeply reduce porosity and permeability of the sandstones. The abundant clay minerals in the Oligocene sandstone reservoir rocks are chlorite and illite. The clays are distinct morphologies and multiarranged patterns in pores as well as on the grain coatings.

Observed illite is in multiple morphologies as illite filaments are either surrounding the detrital grains or replacing in leached unstable minerals such as feldspar, volcanic fragment, kaolinite, etc. Illite ribbons interweave in the form of pore-filling and pore-bridging (figure 2). SEM image shows authigenic illite with ribbons (Il) forming mats interwoven in pore space and chlorite (Ch) in pore space (image A). These illite ribbons like barriers to fluid flow through in pores. Image B is showing illite filaments (II) released from the leached feldspar $(\mathrm{F})$.

As investigated by Tran Van Nhuan, Bui Tri Tam, et al., 2013 [8], illite was formed in the early diagenesis and extended to the burial diagenesis. Illite ribbons thus are created a baffle to fluid flow over pores suggesting that illite has a great effect on the permeability of rocks. 

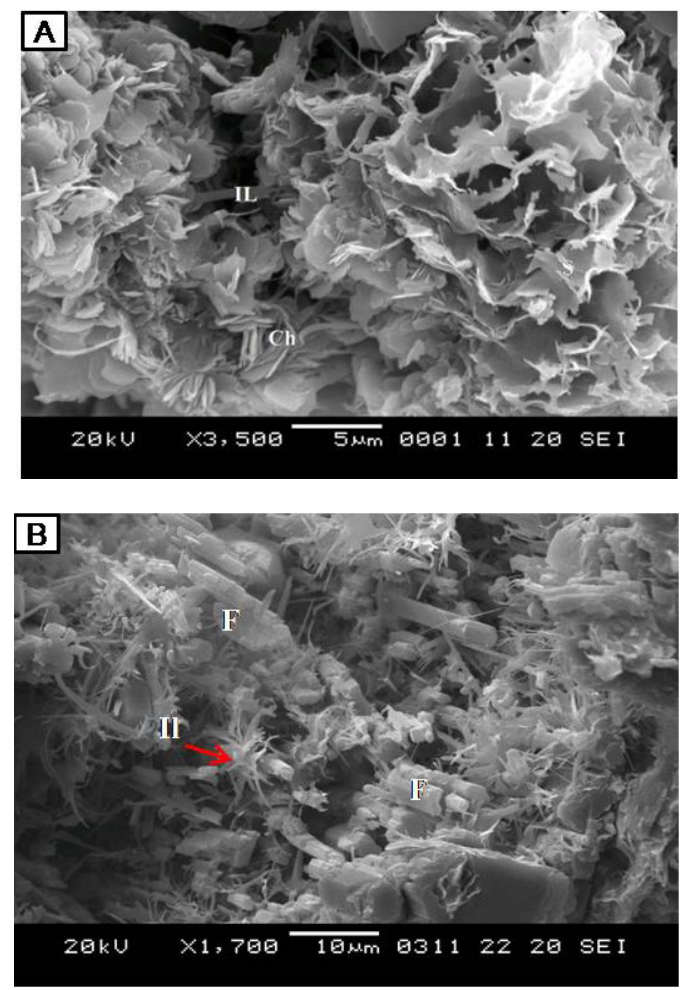

Figure 2: Sample taken from $4100 \mathrm{~m}$ depth in Oligocene sandstone

Chlorite presents in different habits and distribution patterns in the sandstone as individual crystals with euhedral and subeuhedral shapes arranged in rosette pattern, which are filling in pore. Chlorite plates are either growing perpendicular to the grain surfaces or in the form of grain rims (figure 3).

SEM image A is showing pore filling chlorites with platelets arranged in a rosette pattern. The jagged overgrowth of chlorite $(\mathrm{Ch})$ covers a detrital grain surface, as seen in SEM image B. Chlorite platelets are the euhedral and pseudohexagonal crystals growing perpendicular to detrital grain surfaces and facing into pore spaces (image $\mathrm{C}$ ).

Chlorite is probably generated in $\mathrm{Fe}-\mathrm{Mg}$ rich pore waters with supplying $\mathrm{Al}$ and $\mathrm{Si}$ released from dissolved feldspars. In addition, chlorite occurs replacing less stable framework grains, which are ferromagnesian minerals e.g. biotite, volcanic rock fragment, porefilling cement and pore-lining cement. Chlorite is present a great volume in pores of the sandstone. Such chlorite as perpendicular to the grain surfaces is the main cause to decrease both the porosity and permeability of sandstones. Moreover, chlorite completely surrounding quartz surfaces partly limits the growth of quartz overgrowths.
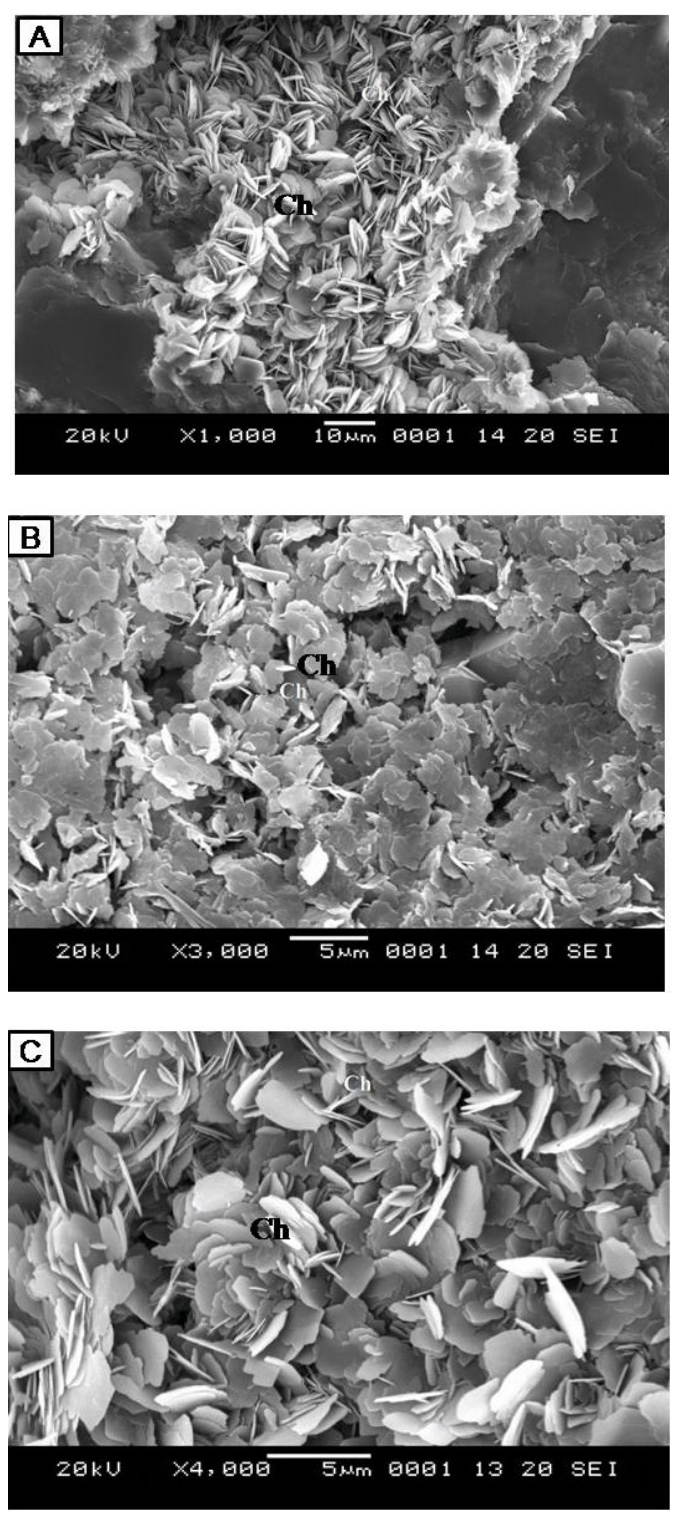

Figure 3: Sample taken from $4200 \mathrm{~m}$ depth in Oligocene sandstone.

Locally, the mixture of illite-smectite or chloritesmectite occurs in a small proportion and less frequently in the sandstones. Therefore, these mixtures are not highly controlling the porosity and permeability of rocks.

\section{DISCUSSION AND CONCLUSION}

In the analyzed Oligocene sandstone reservoir rock sample, the main component of framework grains is

\section{Trang 24}


quartz, alkaline feldspar, plagioclase and amounts of rock fragments. The sandstones are identified as arkose. The detrital grains were deposited in the fluvial and alluvial plain - lacustrine environments. The sandstones have experienced multi diagenetic phases which are indicated by the appearance of authigenic clay minerals. This was demonstrated in a previous study by Tran Van Nhuan, Bui Tri Tam, et al., 2013 [8]. The morphology, amount and distribution patterns of the authigenic clay assemblages in the pore spaces were shown in the result. These illustrate that different clay minerals tend to have variable volume of porosity with them and can have different impacts on permeability because of occurrence in distinct morphologies and positions within pore network. This was evidenced by J.J. Howard, 1992 [9] and P.J. Stalder, 1973 [10]. Illite filaments coating on the grain surfaces may have less effect on permeability than interwoven at pore throats. While chlorites that grow perpendicular on the grain surfaces have more of an influence on permeability than coatings on the grain surfaces. Additionally, in case of chlorite, it depends significantly on distribution pattern that chlorite has a severe impact on both porosity and permeability of sandstones. These results illustrate the effects of authigenic minerals in sandstone reservoir rocks. This is an importantly additional step to estimate the reservoir quality. Furthermore, this is a significant feature for hydrocarbon exploration and exploitation.

Acknowledgements: We gratefully acknowledge authors 16 VPI projects. We thank Analysis Laboratory Center (VPI-Labs), Sedimentology section for supporting the laboratory to carry out this investigation. We also thank PVEP for providing the cores for our research.

\section{Sự thành tạo khoáng vật sét thứ sinh trong quá trình biến đổi sau trầm tích và sự ảnh hưởng của chúng đến độ rỗng và thấm của đá chứa cát kết Oligocene tại một giếng khoan ở phía tây bồn trũng Cửu Long}

- Liêu Kim Phượng

- Hồ Minh Toàn

- Đoàn Thị Thúy

- Bùi Thị Ngọc Phương

Trung Tâm Phân Tích Thí Nghiệm, Viện Dầu Khí Việt Nam (VPI-Labs)

\section{TÓM TÁT:}

Độ rỗng và độ thấm có một vai trò quan trọng trong đá chứa hydrocarbon và dòng chảy của chất lưu vỉa, đặc biệt trong đá chứa cát kết. Độ rỗng của đá giảm dần khi bị chôn vùi sâu do sự nén ép, xi măng và sự kết tinh của khoáng vật thứ sinh trong lỗ rỗng. Vì thế, nghiên cứu về sự thành tạo khoáng vật thứ sinh trong không gian lỗ rỗng của đá chứa cát kết là cần thiết để đánh giá chất lượng chứa của đá.Trong nghiên cứu này, 20 mẫu lôi cát kết tập Oligocene được chọn phân tích với kính hiển vi điện tử (SEM) và lát mỏng (thin section) ở độ sâu từ 3700 m đến 4200 m tại một giếng khoan ở phía Tây bồn trũng Cửu Long, ngoài khơi Việt Nam. Khoáng vật sét thứ sinh được thành tạo do sụ thay đổi nhiệt độ, hóa học và sự hòa tan của những khoáng vật kém bền vững ở sâu. Khoáng vật sét thứ sinh chlorite được thành tạo khá phổ biến và illte kém phổ biến hơn. Chlorite được thành 
tạo bởi những nguyên tố Al, Si được phóng thích từ sự hòa tan của hạt lưu tính và $\mathrm{Fe}, \mathrm{Mg}$ do sự phân hủy của những khoáng vật giàu sắt, magie và khung đá (matrix) được bổ sung vào nước lỗ rỗng. Illite được thành tạo từ sự hòa tan của feldspar và mảnh vụn đá núi lửa. Chlorite thường có dạng tinh thể giả lục giác, bao xung quanh bề mặt hạt hay là phát triển vuông góc với bề mặt hạt. Chlorite bao quanh bề mặt thạch anh có vai trò bảo vệ lỗ rỗng bởi vì chúng ngăn cản sự phát triển của thạch anh thứ sinh trên bề mặt của hạt thạch anh.
Thêm vào đó, illite có dạng sợi bắc cầu giữa các hạt trong lỗ rỗng tạo nên những tấm ngăn cản chất lưu chảy qua lỗ rỗng. Do vậy, illite làm giảm độ thấm một cách đáng kể nhưng ít làm giảm độ rỗng. Smectite-illite và smectite-chlorite không phổ biến trong những mẫu nghiên cứu. Do đó, smectite illite và smectite-chlorite không ảnh hưởng nhiều đến độ rỗng và độ thấm của đá. Sự thay đổi của độ rỗng và độ thấm của những mẫu (cát kết) nghiên cứu phụ thuộc vào múc độ thành tạo và sự sắp xếp của chlorite và illite trong lỗ rông.

Từ khóa: SEM, Chlorite-illite, độ rỗng, độ thấm, cát kết

\section{TÀI LIẸU THAM KHẢO}

[1]. Tran Le Đong and Phung Dac Hai, "Cuu Long basin and Petroleum resource. Geology and Vietnam petroleum resource", Ha Noi, Vietnam petroleum Corporation, pp. 267-341, 2000.

[2]. Hoang Dinh Tien and Nguyen Thuy Quynh, "Condition and oil production mechanism of Kainozoi basins in offshore of Vietnam”, Petro Vietnam Scientific Conference - Oil and gas industry in the $21^{\text {st }}$ century, Ha Noi, Youth Publisher, 2000.

[3]. M. Soloman and R. Green, "A chart for designing modal anaalysis by point couting", Geol. Rdsch,Vol. 55, pp. 844-848, 1966.

[4]. L. Van der Plas and A. C. Tobi, "A chart for judging the reliability of point counting results", Am, J. Sci.,Vol. 263, pp. 87-90, 1965.

[5]. R. L. Folk, "Petrology of Sedimentary Rocks", Austin, Texas 78703, Hemphill Publishing Company, 1974; 1980.

[6]. R. L. Folk and W.C. Ward, "Brazos River bar: a study in the significance of grain size parameters",
Journal of Sedimentary Petrology, Vol. 27, pp. 326, 1957.

[7]. F. J. Pettijohn, "Sedimentary rock", Harper \& Row, 1975.

[8]. Tran Van Nhuan, Bui Tri Tam, et al., "The diagenetics of characteristics of Oligocene reservoirs in Cuu Long basin", Petro Vietnam, Vol. 2, pp. 21-28, 2013.

[9]. J. J. Howard, "Influence of authigenic-clay minerals on permeability. In: Origin, Diagenesis, and Petrophysics of Clay Minerals in Sandstones", Special Publication of the Society of Economic Paleontologists and Mineralogists 47 (Ed. by D.W. Houseknecht and E.D. Pittman), Tulsa, OK, pp. 257-264, 1992.

[10].P. J. Stalder, "Influence of crystalline habit and aggregate structure of authigenic clay minerals on sandstone permeability", Geol. Mijnbouw, Vol. 52, pp. 217-220, 1973.

\section{Trang 26}

